\title{
Comparison of the Narcissism Level of the Bodybuilders before and after the Application of Anabolic Steroid Cure
}

\author{
Ünsal Tazegül \\ School of Physical Education and Sports, Mardin Artuklu University, Mardin, Turkey \\ *Corresponding Author: unsaltazegul@gmail.com
}

Copyright(C2018 by authors, all rights reserved. Authors agree that this article remains permanently open access under the terms of the Creative Commons Attribution License 4.0 International License

\begin{abstract}
The aim of the study was to compare narcissism levels of bodybuilding athletes in elite level before and after anabolic steroid cure. Method: The sample group of the study was composed of a total of 42 bodybuilding athletes who use steroids and voluntarily participated in the study. A control group of 22 people was also established and they did not use steroids. Personality Inventory was used as a data collection tool. 16-question Narcissistic Personality Inventory (NPI-16) was coordinated by Daniel R. Ames and his colleagues at Colombia University. Paired sample t-test and descriptive statistical analysis were applied in the analysis of the data. Results: Before the steroid cure, the athletes' narcissism level was found to be $(8,5714)$, after steroid cure, the athletes' narcissism level was found to be $(13,4286)$. Conclusion: According to the statistical analysis results, it was determined that there was an increase in narcissism levels of the athletes after steroid cure. When this result is evaluated according to the characteristics of narcissistic personality, it can be said that after anabolic steroid cure, athletes more liked their bodily and physical characteristics.
\end{abstract}

Keywords Narcissism, Bodybuilding, Streoid

\section{Introduction}

Narcissism is simply defined as an individual's excessively admiration of his/her physical and mental skills. It is understood from the studies on narcissistic personality that individuals who have developed narcissistic personality excessively appreciate their own physical and bodily characteristics. Sports contribute to the physical and bodily development of the individual and allow the individual to evaluate himself / herself more positively. Self-evaluation and perception of the individuals who achieve beautiful and aesthetic physical appearance through sports are different from the individuals that non-athletes. Not only today, but also in the past, many societies have created the desire to be attractive and good-looking in most people, with the emphasis on appearance, attractiveness, being beautiful and handsome. Therefore, people have begun to exert intensive efforts to look better and to have an aesthetic physique [1].

Narcissist individuals get above themselves physically and mentally, think himself/herself superior, always expect appreciation, interest and approval of the others and they believe that they will immediately attract the attention and that they deserve a priority. It is inevitable that an individual with such intense narcissistic expectations often gets disappointed and be offended. The self-esteem of a narcissistic individual is nourished by the interest, appreciation and approval of others. These people cannot stand criticism and are constantly expecting to be praised. For this reason, their appearance and behavior are always shaped to achieve it. Their friendships are established on gaining personal benefits, as they are using others to glorify themselves, to think themselves superior and to make others to believe that they are superior. Since narcissists cannot show empathy for the feelings, thoughts and needs of others, they are selfish and self-centered in their relationships $[2,3]$.

Narcissistic individuals are selfish because they think that they are unique and special. Because narcissistic individuals have sense of selfishness, they believe that they deserve more than they always get. They are success-oriented. They seek opportunities to increase their self-esteem when they feel a little fear of failure. Narcissistic individuals always strive to look good, and to feel themselves special, successful, important and positive. Sometimes, these self-regulatory efforts can have spiritual 
considerations, such as fantasizes of power or blaming the situation rather than personal failures and sometimes, they have idea of using the others for their own interests in their relationships [4].

When narcissistic athletes fail, they argue referee decisions, incorrectness of the rules, supporters, and incorrect tactics by coaches as reasons for their failures. Therefore, they will not believe that they fail due to their own fault $[5,6]$.

The aim of this study is to compare the levels of narcissism of the elite bodybuilders before and after the steroid cure.

\section{Method}

\section{Study Group}

The study group consists of 42 elite bodybuilding athletes who voluntarily participated in the study. The athletes who participated in the study have applied the Bulk Cure. Bulk Cure is a steroid cure applied from 8 to 16 weeks. The athletes use the following drugs in this cure: Testosterone Enanthate Deca, Boldenon, Trenbolone Enanthate, Dianabol, Anapolon etc. The purpose of this cure is to enlarge the body and to gain muscle. Depending on the use of drug, body fat and water retention can be observed. The control group, consisting of 22 individuals, did not use any steroids. The control group did 3 to 4 days per week for 1 to 2 hours of weight training for 3 months. The athletes in the study group implemented their own training programs.

\section{Data Collection Tools}

\section{Narcissistic Personality Inventory}

Narcissistic Personality Inventory composed of 16 questions and translated into Turkish by Salim Atay in 2009 was used as a scale factor. NPI composed of 16 questions was arranged by Daniel R. Ames, Paul Rose ve Cameron P. Anderson in 2005 translated into Turkish by Salim Atay. After the pilot application by Atay Cronbach's Alpha value was determined as 0,57 in the first performed study. Reliability coefficient below the values expected due to the presence of each factor scale, the negative correlation is detected and evaluated and determined not provide additive scale of four, were revised statement. After the measurements performed this change Cronbach's Alpha value was raised to 0,652 . The questions in 16 questions scale factor translated into Turkish by Atay also distributed in 6 factors as superiority, authority, pretension, self-sufficiency and exploitation similar to the 16 questions NPI English version. he points that can be gained from NPI are: extent of authority $0-2$, extent of exhibitionism $0-3$, extent of exploitation $0-3$, extent of pretension $0-2$, extent of self-sufficiency $0-3$, extent of superiority $0-3$, total narcissism is between $0-16$ points. As the point increases, the level of narcissism also increases $[7,8]$.

\section{Analysis of Data}

SPSS 20 was used for analyzing the data in this research. "Kolmogorov-Smirnov" test was applied to determine that the data had a normal distribution while "Anova-Homogeneity of variance" test was applied to determine its homogeneity and it was found that the data was homogeneous, with a normal distribution. Descriptive statistics and Paired sample t-test were used in the analysis of data.

\section{Results}

Table 1. Descriptive statistical findings

\begin{tabular}{ccccc}
\hline \multicolumn{2}{c}{ Study group } & & \multicolumn{2}{c}{ Control group } \\
\hline & $\overline{\mathrm{x}}$ & \pm & $\overline{\mathrm{x}}$ & \pm \\
\hline $\begin{array}{c}\text { Narcissism first } \\
\text { measurement }\end{array}$ & 8,5714 & 2,82093 & 7,3458 & 2,8549 \\
\hline $\begin{array}{c}\text { Narcissism last } \\
\text { measurement }\end{array}$ & 13,4286 & 1,42539 & 8,2148 & 3,4589 \\
\hline
\end{tabular}

As a result of descriptive statistical analysis, narcissism score of athletes before the implementation of the anabolic steroid cure was determined as 8,5714, whereas the narcissism score after the implementation of the anabolic steroid cure was determined as 13,4286 .

Table 2. Paired sample t-test

\begin{tabular}{cccccc}
\hline \multicolumn{3}{c}{ Study group } & \multicolumn{4}{c}{ Control group } \\
\hline Mean & $\mathrm{t}$ & $\mathrm{p}$ & Mean & $\mathrm{t}$ & $\mathrm{p}$ \\
\hline$-6,85714$ & $-18,908$ &, 000 & $-1,1500$ & $-20,113$ &, 062 \\
\hline
\end{tabular}

A statistically significant difference was determined when narcissism scores of the athletes in the study group were compared before and after the usage of anabolic steroid.

\section{Discussion}

As a result of descriptive statistical analysis, it was determined that the athletes had an increase in narcissism score after anabolic steroid cure. When the scores of the narcissism before and after the anabolic steroid use of the athletes were compared, a statistically significant difference was found. It was found out that the level of narcissism of the athletes in the control group is increased at the least. However, this increase is not statistically significant. Based on these statistical results, it can be asserted that the use of anabolic steroid is effective in the development of narcissistic personality. When this result is 
evaluated according to the characteristics of narcissistic personality, it can be said that after anabolic steroid cure, athletes more liked their bodily and physical characteristics. As a result of anabolic steroid use, the following may be the reason for the increase in the narcissistic personality score:

Increase in the muscle mass of the athletes due to the use of anabolic steroids. Because obtaining positive reactions from the others about their bodies due to the increase in their muscle mass can create a sense of difference in the athletes. In addition, by means of the use of anabolic steroids, the athlete can be instantly recognized within the society and be the focus of attention by reaching the ideal body in his/her mind. Therefore, being the focus of attention and being recognizable with the physical appearance can affect the narcissistic personality development of athletes. In the study they carried out in [9], Cooper, Noakes, Dunne, Lambert and Rochford found out that the individuals who use steroids have higher borderline, antisocial, paranoid, schizotypal, histrionic, passive aggressive and narcissistic personality scores than those who do not use steroids. In some studies conducted on this issue, it was determined that the incidence of antisocial personality disorder was higher among the individuals using steroids when compared to those who did not use it. In the study of Scott-Robertson in [10], it was found out that bodybuilders using steroids were more narcissistic than those who did not use it. In [11], Yavari found the level of narcissism of the athletes performing bodybuilding sports as 27.37. Klein [12] stated that no one can be more narcissistic than athletes in the bodybuilding branch. Klein also stated that they always tend to show off with their proportional aesthetic physics. Blouin and Goldfield [13], found that athletes engaged in bodybuilding sports were more occupied with their physical appearance than other athletes. Carroll [14] found that the narcissistic features of bodybuilding athletes are more developed than the athletes and students in different sports branches. Brown [15], stated that the narcissistic features of bodybuilding athletes are more developed than the non-athletes. In [16], Davis and Robertson found the narcissism level of the bodybuilding athletes as 17.8 . In a study conducted by Porcerelli and Sandler in [17], they found that the narcissism levels of weightlifting and bodybuilding athletes who use steroids were higher than those who did not use steroids.

In conclusion, it has been revealed that the use of steroids affects the level of narcissism of athletes. The primary reason for this is thought to be arising from being the focus of attention as a result of the increase in muscle mass of the athletes through steroids and to be related to achieving the ideal body in their minds. Furthermore, as a result of the literature review, it has been detected that a study comparing narcissism levels of the Turkish athletes before and after steroid cure is not found in Turkish literature. For this reason, it is thought that this study will contribute to the Turkish literature and the future studies.

\section{REFERENCES}

[1] Tazegül, Ü ve Güven, Ö. (2015). Vücut geliştirme sporcuları ile farklı spor dallarındaki elit sporcuların ve spor yapmayan bireylerin narsisizm seviyelerinin karșilaștırılması, The Journal of Academic Social Science, $33,465-473$.

[2] Öztürk, O. (2002). Ruh sağlığ1 ve bozuklukları, (9. Bask1). Ankara: Feryal Matbaası, 436.

[3] Tazegül, Ü. ve Ferah, M. (2016). The determination of the relationship between sports age and the levels of narcissism of female athletes. European Journal of Physical Education and Sport Science, 2(4), 36-44

[4] Campbell, W:K ve Foster, J. D. (2007). The Narcissistik Self: Backgraund, an Extended Agency Model, and Ongoing Controversies. C. Sedikides ve S. Spencer (Eds). Frontiers in Social Psychology: The Self (1-43) Phileadelphia: Psychology Press.

[5] Tazegül, Ü. (2011). Comparison of narcissism in some branches of athletes. International Journal of Sport Studies, 1(4), 168-179.

[6] Tazegül, Ü. (2012). Bireysel sporlardaki sporcuların narsisizm düzeylerinin sosyo demografik özelliklerine göre karşitlaştırılması. 2ND International Social Sciences in Physical Education and Sport Congress. May 31- June 2, Ankara/Turkey.

[7] Atay, S. (2009). Narsist Kișilik Envanterinin Türkçeye Standardizasyonu. Gazi Üniversitesi Iktisadi ve İdari Bilimler Fakültesi Dergisi. 11(1), 181-196.

[8] Atay, S. (2010). Çalışan narsist örgütler, liderler, yöneticiler ve astlar. İstanbul: Namar Yayınları.

[9] Cooper, C.J., Noakes, T.D., Dunne, T., Lambert, M.I., Rochford, K. A (1996). High prevalence of abnormal personality traits in chronic users of anabolic-androgenic steroids. British Journal of Sports Medicine, 30, 246-250.

[10] Scott-Robertson, L. F. (1996). A psychological comparison of competitive male bodybuilders and females diagnosed with anorexia nervosa. Master's thesis, York University Institute of Health Science, Ontario.

[11] Yavari, Y. (2014).Narcissism and its relations with beliefs about body appearance and personal characteristics among elite body builders. International Journal of Sport Studies, 4(4), 394-399.

[12] Klein, A. M. (1987). Fear and self-loathing i n Southern California: Narcissism and fascism in bodybuilding subculture. The Journal of Psychoanalytic Anthropology, 10 (2), 117-137.

[13] Blouin, A.G., Goldfield, G.S. (1995). Body image and steroid use in male bodybuilders. International Journal of Eating Disorders, 18 (2), 159-165.

[14] Carroll, L. A (1989). Comparative study of narcissism, gender, and sex-role orientation among bodybuilders, 
athletes, and psychology students. Psychological Reports, 64(3), 999-1006.

[15] Brown, A. D. (1997). Narcissism, identity, and legitimacy. The Academy of Management Review, 22, 643-686.

[16] Davis, C., Robertson, L. S. (2000). A psychological comparison of females with anorexia nervosa and competitive male bodybuilders: body shape ideals in the extreme, Eating Behaviors, 1, 33-46.

[17] Porcerelli, H.J., Sandler, A. B. (1995). Narcissism and Empathy in Steroid Users. American Journal of Psychiatry, (152), 1672-1674. 